\title{
Practical use of immobilized lysozyme for the remediation process of Escherichia coli in aqueous solution
}

\author{
Carlucio R. Alves* \\ Environmental Biotechnology Group \\ State University of Ceará \\ 60.640-020 Fortaleza, Ceará, Brazil \\ Tel: 558531019822 \\ Fax: 558532992500 \\ E-mail: alvescr@yahoo.com \\ Maria Gardenny R. Pimenta \\ Environmental Biotechnology Group \\ State University of Ceará \\ 60.640-020 Fortaleza, Ceará, Brazil \\ Tel: 558531019822 \\ Fax: 558532992500 \\ E-mail: gardenny@yahoo.com.br

\section{Regine H.S.F. Vieira} \\ Science Institute - Labomar \\ Federal University of Ceará \\ 60.165-081 Fortaleza, Ceará, Brazil \\ Tel: 558531019822 \\ Fax: 558532992500 \\ E-mail: regine@labomar.ufc.br

\section{Roselayne F. Furtado} \\ Environmental Biotechnology Group \\ State University of Ceará \\ 60.640-020 Fortaleza, Ceará, Brazil \\ Tel: 558531019822 \\ Fax: 558532992500 \\ E-mail: roselayneff@hotmail.com \\ Maria Izabel F. Guedes \\ Environmental Biotechnology Group \\ State University of Ceará \\ 60.640-020 Fortaleza, Ceará, Brazil \\ Tel: 558531019822 \\ Fax: 558532992500 \\ E-mail: florinfg@terra.com.br
}

Rui C.B. Silva

Environmental Biotechnology Group State University of Ceará

60.640-020 Fortaleza, Ceará, Brazil

Tel: 558531019822

Fax: 558532992500

E-mail: rcbs@uece.br

\section{Odilio B.G. Assis}

Embrapa Agricultural Instrumentation Center

Caixa Postal 741, 13560-970

São Carlos, SP, Brazil

Tel: 55162742477

Fax: 55162725958

E-mail: odilio@cnpdia.embrapa.br

Financial support: This project was financed by a grant from FUNCAP, FAPESP and CNPq.

Keywords: Escherichia coli, lysozyme, self-assembly.

*Corresponding author 
The lysozyme enzyme was immobilized on vitreous surface (fragments with diameters of 0.3 and $1.0 \mathrm{~mm}$ ) for remediation of the microorganism Escherichia coli JM 109 into fresh water and saline solutions with $0.9 \%$ $\mathrm{NaCl}(\mathrm{w} / \mathrm{v})$. Characterization of enzymatic film was carried out by infrared spectroscopy and atomic force microscopy techniques. Bactericide activity of the enzyme was evaluated by spectrophotometric analysis. It was verified that the enzymatic film was strongly coupled with the vitreous surface. The topographic analysis demonstrated that the deposited film was uniform and homogeneous. It was observed bactericide activity of film deposited on vitreous surface with 0.3 $\mathrm{mm}$ in fresh and saline solutions. This fact was not verified to vitreous fragments with $1.0 \mathrm{~mm}$ of diameter.

The constant expansion of different human activities carries into the water certain types of microorganisms that can be incorporated in our alimentary chain. Therefore, mankind should be concerned for microbiologic decontamination standards and looking for actions that be able to limit additional risks to the public health: the chronic effects of contamination of the environment.

The conventional treatments used, nowadays, not eliminate totally the micro contaminants of biological origin. This fact demands that water sources be free from microorganisms or if this is impossible, more appropriate methods of treatment should be applied.

The polymeric films have been classified and proved to be applicable to eliminate, from several origins, contaminated particles from water. Weber-Shirk and Dick (1997) have reported the considerable efficiency in the removal of bacteria, such as, Escherichia coli, protozoans and the poliovirus in water by filtration into hydrophilic membranes and superficial films of polymeric structures. Ruggaber and Talley (2006) highlighted the great potential of the enzymatic films for remediation of polluted environments. The advantage of polymeric films are mechanic resistance, the control of thickness and growth rate (Liapis et al. 1989; Marino et al. 2003; Lavigne et al. 2004; Conte et al. 2006; Ruggaber and Talley, 2006).

The fundamental requirement for biological film fixation is that when in solution, the molecules show regions with defined superficial charges for electrostatic interaction. On the whole, the self-assembly technique is very simple due to the proper procedures, equipments and raw materials used in its preparation. The organic layers are obtained by successive immersions in aqueous solutions followed by drying process of these deposited layers. The final properties and the structure of the self-assembly films depend on the experimental parameters (solvents, concentrations, ionic strength, $\mathrm{pH}$ etc.), which can affect the final permeability of the membrane (Borato et al. 1997; Knight et al. 2000; Shing-Yi et al. 2000; Miano et al. 2005; Pechkova et al. 2005).
There are different supports for enzymatic immobilization, for example, chitosan and alumina (Sobral et al. 2003). Indubitable, the largest advantage of the use of enzymatic film is that the method used has high capacity to process required chemical reactions.

The lysozyme film has called researches' attention in last years on account of the enzymatic activity being useful in the attack on many bacteria, with the breaking of mucopolysaccharides structure of the cell wall (Masschalck et al. 2001; Datta et al. 1973; Park et al. 2004). Moreover, the lysozyme has an important characteristic, when crystallized, it supports temperatures up to $120^{\circ} \mathrm{C}$ without perceiving the loss of its enzymatic activity (Kudou et al. 2003; Lavigne et al. 2004).

The lysozyme film acts directly on gram positive bacteria and there is the possibility of interaction with phospholipids of external membrane of gram negative bacteria. It checks the enzyme, thus functions as a protection together with large amounts of biological fluids where the same is found (Masschalck et al. 2001; Min et al. 2005). The specific function of enzyme is represented by a deep opening inside the molecule. Inside this enzyme, the residues Glu-35 and Asp-52 are responsible for the hydrolysis of the glycosidic connection. It is believed that the Glu-35 has an acelylic link to the substrate, while the negative charge of the Asp52 stabilizes the result of the ion cation (Datta et al. 1973; Dehong and Lu, 2004).

This work had the objective to evaluate the practical use of the immobilized lysozyme enzyme on vitreous surface for remediation process of pathogenic microorganism

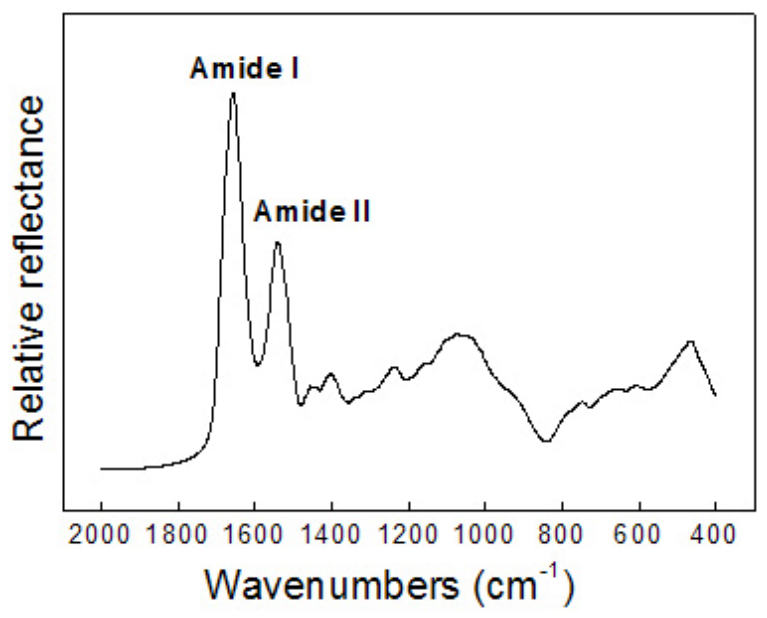

Figure 1. Infrared spectrum for the lysozyme film deposited on vitreous fragments with diameters of $0.3 \mathrm{~mm}$. The tops amide I and amide II correspond to 1542 and $1659 \mathrm{~cm}^{-1}$, respectively. 
Escherichia coli JM 109 found in fresh water and saline solution.

\section{MATERIALS AND METHODS}

\section{Preparation of the surface and film deposition}

The lysozyme film was prepared using the self-assembly technique, which is based on spontaneous irreversible adsorption of the protein. The deposition of the enzyme occurs though covalent chemical bonding between the substrate and the absorbent (Dickerson and Geis, 1993).

The substrate (fragments of glass of 0.3 and $1.0 \mathrm{~mm}$ ) was submitted to chemical cleaning and hydrophilization, according to method proposed by Borato et al. (1997). $\mathrm{H}_{2} \mathrm{SO}_{4}$ (Merck) and $\mathrm{H}_{2} \mathrm{O}_{2}$ (Merck) solutions were prepared in proportions of $(7: 3, \mathrm{v} / \mathrm{v})$. Afterwards, the fragments of glass were immerged in this solution at temperature of $80^{\circ} \mathrm{C}$ for $30 \mathrm{~min}$, followed by exhaustive washes in Milli-Q distilled water.

These same surface was submitted to solution of $\mathrm{H}_{2} \mathrm{O} / \mathrm{H}_{2} \mathrm{O}_{2}$ (Merck) $/ \mathrm{NH}_{4} \mathrm{OH}$ (Merck) in proportions of $(5: 1: 1, \mathrm{v} / \mathrm{v})$ at temperature of $80^{\circ} \mathrm{C}$. This procedure was carried out for 30 $\mathrm{min}$ and later were done various washes in distilled water.

This series of actions generated negative charges onto the glass surface.

The lysozyme aqueous solution from hen egg-white lysozyme (Sigma Chemical, 99\%, 47,000 unit $\mathrm{mg}^{-1}$, in the lyophilic form) was prepared in concentration of $10^{-4} \mathrm{~mol}$ $\mathrm{L}^{-1}$ and $\mathrm{pH} 6.4$ under moderate agitation for $4 \mathrm{hrs}$.

The enzymatic film was immobilized by immersion of the vitreous surface into the lysozyme aqueous solution for 2 hrs under gentle agitation. They were dried under vacuumed at room temperature.

The atomic force microscope (TopoMetrix model TNX 2010) and the infrared spectrometer with Fourier analysis (BOMEM model DA8) coupled with MCT detector were utilized to confirm the presence of the film on the vitreous surface.

\section{Preparation of contaminated solution with Escherichia coli JM 109}

The Escherichia coli JM 109 stump was isolated from Eosin Methylene Blue Agar (Merck) and the growth of the colony was made in Trypticase Soy Agar (Merck), at $23^{\circ} \mathrm{C}$, in incubator BOD (Fanem model 347).

The growth of the bacteria occurred in mixture EC Bouillon (Merck). The tubes remained in water bath at temperature of $44.5^{\circ} \mathrm{C}$ for $24 \mathrm{hrs}$. The development of the colony was detected visually although turbidness and the formation of gas in Duhran tube.

\section{Building of the filtration column}

The column, in which the filtration was carried out, was constituted of two separable bodies and united by thread

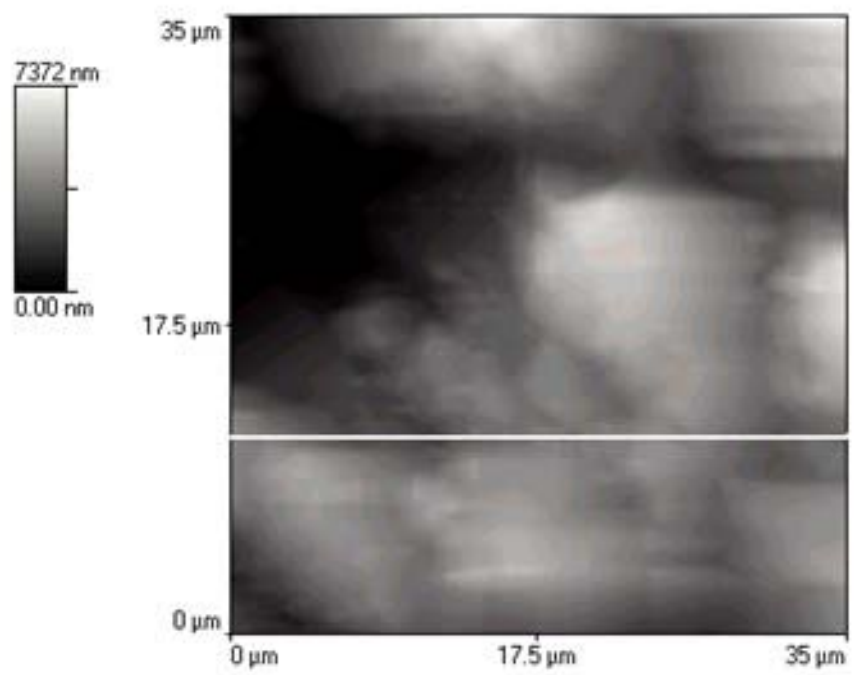

(a)

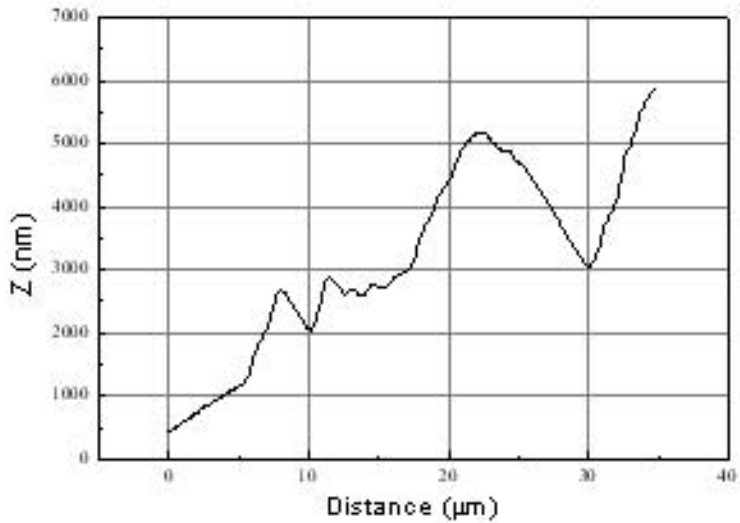

(b)

Figure 2. Lysozyme film deposited on vitreous fragments with diameters of $0.3 \mathrm{~mm}$.

(a) Topographic Micrograph of the vitreous substrate with diameter of $0.3 \mathrm{~mm}$.

(b) Graphic representation of the covered surface with proteic film. 
system. The superior part was formed by an acrylic tube of capacity of $50 \mathrm{~mL}$ whereas the inferior part was made of glass and had a tap.

\section{Monitoring of the bactericide activity of the enzyme}

The substrate of recycled glass with different sizes covered with lysozyme enzyme was packed inside filtration column. The Escherichia coli JM 109 solution was diluted in fresh water and salt water with solution of $0.9 \% \mathrm{NaCl}(\mathrm{w} / \mathrm{v})$ and added slowly into column.

The analysis of affluent (solution that drained off from the column) was performed by spectrophotometric measurements (Shimadzu model 1601PC) and the efficiency evaluation followed the Kawabata et al. (1996) relation:

$$
\text { Efficiency }(\%)=\left(\mathrm{PFU}_{\text {inf }}-\mathrm{PFU}_{\text {eff }}\right) / \mathrm{PFU}_{\text {inf }} \times 100
$$

Where $\mathrm{PFU}_{\text {inf }}$ and $P F U_{\text {eff }}$ are the concentration of the specimens in the influent (solution added into column) and affluent suspension, respectively. The tests of bactericide activity were done in triplicate in order to have reliable results.

\section{RESULTS AND DISCUSSION}

\section{Presence of immobilized lysozyme on vitreous substrate}

After depositing the lysozyme film on vitreous surface (fragments with diameters for values 0.3 and $1.0 \mathrm{~mm}$ ), measurements of infrared spectrometry were carried out to confirm the deposit formation (Pérez and Griebenow, 2000) and the topographic analysis were done to verify its distribution.

The Figure 1 illustrates the infrared spectrum ranging between 400 to $2000 \mathrm{~cm}^{-1}$ for lysozyme film on vitreous fragments with diameters of $0.3 \mathrm{~mm}$. The bands ranging between 1237 and $1401 \mathrm{~cm}^{-1}$ are related to amino acid tryptophane; another characteristic of the lysozyme is also observed in the region between 1530 and $1700 \mathrm{~cm}^{-1}$ (bands in 1542 and $1659 \mathrm{~cm}^{-1}$ ), which corresponds to the amino band, as verified in the literature (Alix et al. 1985). The bands were similar for the two granulometries confirming the presence of lysozyme on them.

Figure $2 \mathrm{a}$ is a topographic image of small part of the vitreous substrate with diameter of $0.3 \mathrm{~mm}$ covered with the enzymatic film, made up of approximately 30 overlapping layers (Borato et al. 1997).

Figure $2 b$ is a graphic representation of a part of the covered surface with proteic film. It is noted that the vitreous surface is covered homogeneously by enzymatic film. The topographic analysis in micrometric scale not revealed difference between the two granulometries.

\section{Bactericide activity of protein film}

Previous experiments showed promising results for bactericide activity of immobilized lysozyme on vitreous substrates with diameters equal or inferior to $0.3 \mathrm{~mm}$. However, size of fragments smaller than $0.3 \mathrm{~mm}$ have as disadvantage to provide slow speed of liquid by column. In this work, we showed glass fragments with granulometries of $1.0 \mathrm{~mm}$ to compare size bigger than $0.3 \mathrm{~mm}$.

We also tested high concentration of microorganisms and dissolved salt in water to evaluate if in extreme conditions the enzymatic activity was remained. In comparative experiments prepared with fresh water and salt-water solutions, it was noticed that the enzyme maintains its bactericide activity for concentrated solutions with approximately 6,000 bacteria $/ \mathrm{cm}^{3}$.

We used the spectrophotometric technique because this is one of the simplest ways to determine the density of a bacterial culture. In dense culture, the light is scattered, and less light reaches the phototube of the spectrophotometer. In fact, turbidity is more closely related to cell biomass (cell dry weight) than to the number of cells present. In dilute samples, absorbance is directly proportional to biomass.

In the presence of the immobilized lysozyme occurs the rupture cell of the bacteria. This fact is evidenced with a significant decrease in the optical density of wavelength $600 \mathrm{~nm}$ (visible spectrum). We verified that in the presence of lysozyme the optical density showed a progressive decrease of the turbidity, resultant from effect of the bactericide activity. Moreover, it was observed that this activity has shown reduction of the turbidness on the first $30 \mathrm{~mL}$, confirming the process of lysis cell as presented in Figure 3. After sieving $30 \mathrm{~mL}$ of contaminated solution in column, it was noted decreases in remediation process, probably owing to the fact that the film is covered with

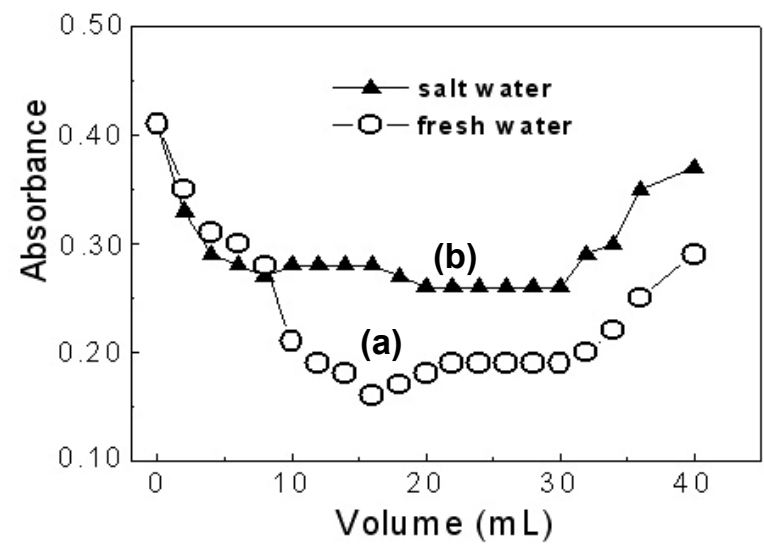

Figure 3. Bactericide activity of the lysozyme deposited on vitreous granular surface of $0.3 \mathrm{~mm}$, for Escherichia coli in fresh water and salt water. 


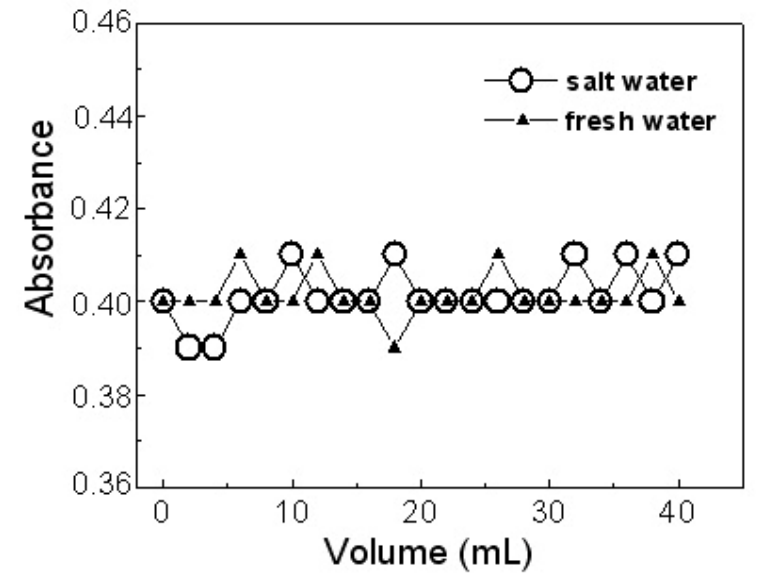

Figure 4. Action of lysozyme film deposited on vitreous granular surface of $1.0 \mathrm{~mm}$ against bacteria in fresh water and salt water.

bacterial fragments, thereby, hindering the effective action of the enzyme.

Figure 3 (curve a) indicates that the bactericide efficiency of lysozyme in fresh water was on average $60 \%$, this results are near to 50\% found for Assis and Claro (2003). On the other hand, in curve $b$, for the saline solution, the efficiency was on average $30 \%$. It was observed that the activity of the immobilized enzyme is reduced because of the presence of ions (electrolytic solution of $\mathrm{NaCl}$ ). According to Campbell and Dwek (1984), when ions are present, the lysozyme in solution undergoes a modification in its conformation. In this way, there is a great loss of the enzymatic activity.

The influence of the glass particles with immobilized lysozyme in the remediation efficiency, it was also tested on vitreous surface with diameter of $1.0 \mathrm{~mm}$. In Figure 4, it is no observed variation in the absorbance for solutions of bacteria, indicating that there is no bactericide activity of the lysozyme. The glass fragments with diameter of $1.0 \mathrm{~mm}$ leave big spaces for bacterial solution to drain off by column. This fact becomes ineffective the percolation process because the time of contact between immobilized protein and Escherichia coli is very short, thus the solution of microorganism passes by enzymatic film without undergoing bactericide action of the lysozyme.

In this work, we demonstrated that the lysozyme efficiency in the remediation process depend on size substrate and other factors that can affect the enzyme and consequently the specific action sites, as was seen in saline medium.

\section{CONCLUDING REMARKS}

Lysozyme enzymatic film grew on recycled glass fragments of $0.3 \mathrm{~mm}$ has potential for applications in decontamination systems, especially in no saline medium, in function of the good bactericide activity and the low cost. Contra wise, the enzymatic film deposited on fragments of $1.0 \mathrm{~mm}$ had not bactericide action in solutions with approximately 6,000 bacteria $/ \mathrm{cm}^{3}$. One of the biggest problems for the practice application of methodology developed (decontamination system) is in the fact of fragments of bacteria's cell wall to accumulate on the enzymatic film obstructing the lysis of other bacteria.

\section{REFERENCES}

ALIX, A.J.P.; BERNARD, L. and MANFAIT, M. Spectroscopy of Biological Molecules. New York, John Wiley \& Sons, $1985.167 \mathrm{p}$.

ASSIS, Odilio B.G. and CLARO, Luis C. Immobilized lysozyme protein on fibrous medium: Preliminary results for microfiltration applications. Electronic Journal of Biotechnology [online]. 15 August 2003, vol. 6, no. 2 Available from: http://www.ejbiotechnology.info/content/vol6/issue2/full/1/ index.html. ISSN 0717-3458.

BORATO, C.E.; HERMANN, P.S.P.; COLNAGO, L.A.; OLIVEIRA Jr., O.N. and MATTOSO, L.H.C. Using the self-assembly technique for the fabrication of ultra-thin films of a protein. Brazilian Journal of Chemical Engineering, December 1997, vol. 14, no. 4, p. 367-373.

CAMPBELL, I.D. and DWEK, R.A. Biological spectroscopy. California, Benjamin/Cummings Publishing Company Inc., 1984. 404 p. ISBN 080531847X.

CONTE, A.; BUONOCORE, G.G.; BEVILACQUA, A.; SINIGAGLIA, $M$. and DEL NOBILE, M.A. Immobilization of lysozyme on polyvinylalcohol films for active packaging applications. Journal of Food Protection, April 2006, vol. 69, no. 4, p. 866-870.

DATTA, R.; ARMIGER, W. and OLLIS. D.F. Lysis of Micrococcus lysodeikticus by lysozyme covalently immobilized on cellulose and polyacrylamide. Biotechnology and Bioengineering, September 1973, vol. 15, no. 5, p. 993-1006.

DEHONG, Hu and LU, H. Peter. Placing single-molecule T4 lysozyme enzymes on a bacterial cell surface: toward probing single-molecule enzymatic reaction in living cells. Biophysical Journal, July 2004, vol. 87, no. 1, p. 656-661.

DICKERSON, Richard E. and GEIS, Irving. Structure and action of protein. California, Benjamin/Cummings Publishing Company Inc., 1993. 257 p. ISBN 0-80-5323910 .

KAWABATA, Nariyoshi; FUJITA, Isao and INOUE, Tsuyoshi. Removal of virus from water by filtration using microporous membranes made of poly ( $N$-benzyl-4vinylpyridinium chloride). Journal of Applied Polymer Science, May 1996, vol. 60, no. 6, p. 911-917. 
KNIGHT, Kirsty; BARROS PIMENTEL, Maria do Carmo; CAMARGO DE MORAIS, Marcia Maria; LEDINGHAM, William M.; DE LIMA FILHO, José Luiz and DINIZ MAIA, Maria de Mascena. Immobilization of lipase from Fusarium solani FS1. Brazilian Journal of Microbiology, July-September 2000, vol. 31, no. 3, p. 220-222.

KUDOU, Motonori; SHIRAKI, Kentaro; FUJIWARA, Shinsuke; IMANAKA, Tadayuki and TAKAGI, Masahiro. Prevention of thermal inactivation and aggregation of lysozyme by polyamines. European Journal of Biochemistry, November 2003, vol. 270, no. 22, p. 45474554.

LAVIGNE, R.; BRIERS, Y.A.; HERTVELDT, K.A.; ROBBEN, J. and VOLCKAERT, G. Identification and characterization of a highly thermostable bacteriophage lysozyme. Cellular and Molecular Life Sciences, November 2004, vol. 61, no. 21, p. 2753-2759.

LIAPIS, A.I.; ANSPACH, B.; FINDLEY, M.E.; DAVIES, J.; HEARN, M.T.W. and UNGER, K.K. Biospecific adsorption of lysozyme onto monoclonal antibody ligand immobilized on nonporous silica particles. Biotechnology and Bioengineering, August 1989, vol. 34, no. 4, p. 467477.

MARINO, G.; FERRARINI, V.; GIARDINI, S. and BIAVATI, B. Use of lysozyme for treatment of bacterial contamination in vitro shoot cultures of fruit plants. In Vitro Cellular and Developmental Biology-Plant, May 2003, vol. 39, no. 3, p. 327-331.

MASSCHALCK, Barbara; VAN HOUDT, Rob; VAN HAVER, Ellen G.R. and MICHIELS, Chris W. Inactivation of gram-negative bacteria by lysozyme, denatured lysozyme, and lysozyme-derived peptides under high hydrostatic pressure. Applied and Environmental Microbiology, January 2001, vol. 67, no. 1, p. 339-344.

MIANO, F.; CALCARA, M.; MILLAR, T.J. and ENEA, $\mathrm{V}$. Insertion of tear proteins into a meibomian lipids film. Colloids and Surfaces B: Biointerfaces, July 2005, vol. 44, no. 1, p. 49-55.

MIN, S.; HARRIS, L.J. and KROCHTA, J.M. Antimicrobial effects of lactoferrin, lysozyme, and the lactoperoxidase system and edible whey protein films incorporating the lactoperoxidase system against Salmonella enterica and Escherichia coli O157:H7. Journal of Food Science, September 2005, vol. 70, no. 7, p. 332-338.

PARK, S.I.; DAESCHEL, M.A. and ZHAO, Y. Functional properties of antimicrobial lysozyme-chitosan composite films. Journal of Food Science, October 2004, vol. 69, no. 8, p. 215-221.

PECHKOVA, E.; VASILE, F.; SPERA, R.; FIORDORO, S. and NICOLINI, C. Protein nanocrystallography: growth mechanism and atomic structure of crystals induced by nanotemplates. Journal of Synchrotron Radiation, November 2005, vol. 12, no. 6, p. 772-778.

PÉREZ, Caroline and GRIEBENOW, Kai. Fouriertransform infrared spectroscopic investigation of the thermal denaturation of hen egg-white lysozyme dissolved in aqueous buffer and glycerol. Biotechnology Letters, December 2000, vol. 22, no. 23, p. 1899-1905.

RUGGABER, Timothy P. and TALLEY, Jeffrey W. Enhancing bioremediation with enzymatic processes: A Review. Practice Periodical of Hazardous, Toxic, and Radioactive Waste Management, April 2006, vol. 10, no. 2, p. 73-85.

SHING-YI, Suen; RUI-LONG, Chen and YI-DA, Tsai. Comparison of lysozyme adsorption to immobilized cibacron blue 3GA using various membrane supports. Journal of Liquid Chromatography and Related Technologies, 2000, vol. 23, no. 2, p. 223-239.

SOBRAL, Keli A.; RODRIGUES, Regina O.; OLIVEIRA, Rogério D.; OLIVO, José E.; DE MORAES, Flávio F. and ZANIN, Gisella M. Evaluation of supports and methods for immobilization of enzyme cyclodextringlycosyltransferase. Applied Biochemistry and Biotechnology, April 2003, vol. 108, no. 1-3, p. 809-820.

WEBER-SHIRK, L.M. and DICK, R.I. Physical-chemical mechanisms in slow sand filters. Journal American Water Works Association, January 1997, vol. 89, no. 1, p. 87-100. 